\title{
Synthesis and stability of quasicrystalline phase in Al-Cu-Fe-Si mechanically alloyed powders
}

\author{
Mikołaj Mitka ${ }^{1}$, Anna Góral ${ }^{1}$, and Lidia Lityńska-Dobrzyńska ${ }^{1, *}$ (1) \\ ${ }^{1}$ Institute of Metallurgy and Materials Science Polish Academy of Sciences, 25 Reymonta St, 30-059 Krakow, Poland
}

Received: 28 November 2020

Accepted: 22 February 2021

Published online:

9 March 2021

(C) The Author(s) 2021

\begin{abstract}
The effect of $\mathrm{Si}$ addition on a quasicrystalline phase formation in Al-Cu-Fe-Si alloys prepared by mechanical alloying has been investigated using X-ray diffraction and scanning and transmission electron microscopy. Two compositions containing 10 at.\% of $\mathrm{Si}$ were selected to verify the influence of the e/a ratio on a sequence of phase formation during milling: $\mathrm{Al}_{58.5} \mathrm{Cu}_{18} \mathrm{Fe}_{13.5} \mathrm{Si}_{10}$ (e/ $\mathrm{a}=1.98)$ and $\mathrm{Al}_{53.5} \mathrm{Cu}_{19.5} \mathrm{Fe}_{17} \mathrm{Si}_{10}(\mathrm{e} / \mathrm{a}=1.75)$. A quasicrystalline icosahedral phase (i-phase) was found in both alloys after $10 \mathrm{~h}$ of milling in the form of nano-quasicrystallites with the size of $10-20 \mathrm{~nm}$. Addition of Si stabilized the quasicrystalline phase being dominant after prolonged milling time, contrary to the reference ternary $\mathrm{Al}_{65} \mathrm{Cu}_{20} \mathrm{Fe}_{15}$ powder, which apart of the quasicrystalline phase contained the cubic $\beta-\mathrm{Al}(\mathrm{Cu}, \mathrm{Fe})$ phase. Thermal stability of the quasicrystalline phase in the powders milled for $10 \mathrm{~h}$ was examined after annealing at $800{ }^{\circ} \mathrm{C}$ for $4 \mathrm{~h}$. The i-phase was preserved partially in $\mathrm{Al}_{53.5} \mathrm{Cu}_{19.5} \mathrm{Fe}_{17} \mathrm{Si}_{10}$ and reference $\mathrm{Al}_{65} \mathrm{Cu}_{20} \mathrm{Fe}_{15}$ powders (both with a ratio e/a = 1.75), which coexisted with $\beta-\mathrm{Al}(\mathrm{Cu}, \mathrm{Fe})$ and $\mathrm{Al}_{13} \mathrm{Fe}_{4}$ phase or $\alpha-\mathrm{Al}_{55} \mathrm{Si}_{7} \mathrm{Cu}_{25.5} \mathrm{Fe}_{12}$ and $\mathrm{Al}_{2} \mathrm{Fe}_{3} \mathrm{Si}_{3}$ phases in $\mathrm{Al}_{65} \mathrm{Cu}_{20} \mathrm{Fe}_{15}$ and $\mathrm{Al}_{53.5} \mathrm{Cu}_{19.5} \mathrm{Fe}_{17} \mathrm{Si}_{10}$, respectively. For the $\mathrm{Al}_{58.5} \mathrm{Cu}_{18} \mathrm{Fe}_{13.5} \mathrm{Si}_{10}$ powders $(\mathrm{e} / \mathrm{a}=1.98)$, the annealing led to complete transformation of the i-phase to the cubic $\alpha-\mathrm{Al}_{55} \mathrm{Si}_{7} \mathrm{Cu}_{25.5} \mathrm{Fe}_{12.5}$ approximant, forming crystallites with a size of $100-300 \mathrm{~nm}$.
\end{abstract}

Handling Editor: Sophie Primig.

Address correspondence to E-mail: 1.litynska@imim.pl 


\section{GRAPHICAL ABSTRACT}

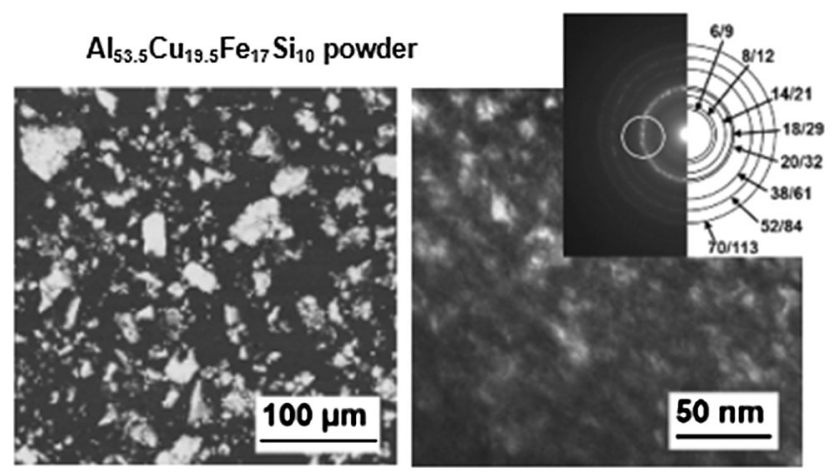

\section{Introduction}

The stable quasicrystalline phase in the $\mathrm{Al}-\mathrm{Cu}-\mathrm{Fe}$ system was first identified in 1987 by Tsai et al. [1] in the massive $\mathrm{Al}_{65} \mathrm{Cu}_{20} \mathrm{Fe}_{15}$ alloy cast by a conventional method and then annealed. This ternary alloy, characterized by low cost, easily accessible, recyclable and non-toxic constituent elements, has been extensively studied in the following years due to possibility of a number of applications [2-5]. In the Al-Cu-Fe system, the thermodynamically stable icosahedral phase exists in a narrow temperature range $\left(750-850{ }^{\circ} \mathrm{C}\right)$ with composition near $\mathrm{Al}_{62} \mathrm{Cu}_{25.5} \mathrm{Fe}_{12.5}$ and is usually accompanied by other crystalline phases [6-8]. It has been reported that the addition of a fourth alloying component has resulted in modification of the microstructure and forming a single-phase quasicrystalline alloy. In the quaternary $\mathrm{Al}_{65} \mathrm{Cu}_{20} \mathrm{Fe}_{12} \mathrm{M}_{3}$ alloys, in which iron atoms were partially replaced with other elements: $\mathrm{Ti}, \mathrm{V}, \mathrm{Cr}, \mathrm{Mn}, \mathrm{Co}, \mathrm{Ni}, \mathrm{Si}, \mathrm{Ge}, \mathrm{Zr}$, $\mathrm{Nb}$, only alloys containing $\mathrm{Mn}, \mathrm{Co}$ and $\mathrm{Si}$ were characterized by a single-phase icosahedral structure [9].

The effect of addition of Si depends on the amount of element added, the content of other components and the method of preparation [10-13]. In the conventionally cast alloys, the volume fraction of the icosahedral phase decreased when silicon atoms replaced aluminum by up to 10 at. $\%[10,11]$. On the other hand, the research conducted by Sukhova et.al. [14] showed that Al substitution by $4-7$ at.\% of $\mathrm{Si}$ in the $\mathrm{Al}_{60} \mathrm{Cu}_{25} \mathrm{Fe}_{12}$ can promote the formability of i-phase, especially in the slow cooled alloys. It was also found that when the Si content increased up to 15 at.\%, the icosahedral phase was replaced by the cubic approximant of $\mathrm{AlCuFeSi}$ [10]. This $\alpha-\mathrm{Al}_{55} \mathrm{Si}_{7-}$ $\mathrm{Cu}_{25.5} \mathrm{Fe}_{12.5}$ phase with a cubic structure, a lattice constant $a=12.330 \AA$ and the Pm-3 point group contains 135 atoms in the unit cell [15-17]. The formation of the $\alpha-\mathrm{Al}_{55} \mathrm{Si}_{7} \mathrm{Cu}_{25.5} \mathrm{Fe}_{12.5}$ approximant can be supported by increasing the cooling rate during casting: moderate rate of solidification can improve the thermal stability of the quasicrystalline phase in the melt spun ribbon, while the higher quenching rates instigate the transformation of the quasicrystal into the cubic approximant [11]. Karaköse and Keskin [18] reported an increase of microhardness and reduction of the number of phases in the rapidly solidified $\mathrm{Al}_{64} \mathrm{Cu}_{20} \mathrm{Fe}_{12} \mathrm{Si}_{4}$ ribbons compared to the conventionally cast alloys.

Mechanical alloying, one-step procedure to obtain material in the form of powder, can lead to formation of a quasicrystalline phase in ternary $\mathrm{Al}-\mathrm{Cu}-\mathrm{Fe}$ alloys [19-24] and extends its composition range compared to the other methods. It was reported that substitution of 5 at.\% of Fe by Si increases the stability of the i-phase and the cubic approximant in the mechanically alloyed and annealed $\mathrm{Al}_{65} \mathrm{Cu}_{20} \mathrm{Fe}_{15}$ powder [12] Murty et al. [13] showed that mechanical alloying of $\left(\mathrm{Al}_{60} \mathrm{Cu}_{25} \mathrm{Fe}_{12}\right)_{100-x} \mathrm{Si}_{x}$ alloys improves the quasicrystalline phase forming ability (QFA) in comparison to rapid solidification processing by extending the range of e/a ratio, over which the icosahedral phase 
can be obtained. It was found also that thermal stability of the quasicrystalline phase in Si-containing alloys increases up to $1223 \mathrm{~K}$.

In the present study, the influence of $\mathrm{Si}$ addition on the formation of the quasicrystalline phase in Al-CuFe-Si alloys prepared by mechanical alloying has been investigated. To verify the effect of ratio of the number of valence electrons to number of atoms in unit cell (e/a), an important parameter for the formation of quasicrystalline phases $[25,26]$, on the sequence of phase formation during milling process two alloy compositions (both containing 10 at.\% of Si) were selected. The first composition with e/a ratio close to 2 corresponded to the alloy described by Murty et al. [13]; the second one with e/a equal 1.75 was identical as for the ternary $\mathrm{Al}_{65} \mathrm{Cu}_{20} \mathrm{Fe}_{15}$ alloy. Parameters of milling process were chosen based on our previous examination, where the single icosahedral phase formed in the $\mathrm{Al}_{65} \mathrm{Cu}_{20} \mathrm{Fe}_{15}$ powder directly after $10 \mathrm{~h}$ of milling at the speed of $350 \mathrm{rpm}$ (revolution per minute) [24]. Additionally, the structural evolution induced by a subsequent annealing and thermal stability of the quasicrystalline phase was studied and compared to the reference ternary composition.

\section{Materials and methods}

Elemental powders of aluminum, copper, iron and silicon (of purity at least $99.2 \%$ and the particle size in the range of 7-15 $\mu \mathrm{m}$, supplied by Alfa Aesar) were mechanically alloyed in a planetary high-energy ball mill Fritsch P5. Mixture of pure elements powder, corresponding to the compositions presented in Table 1, was milled in tungsten carbide (WC) vials together with WC balls under argon atmosphere (the ball to powder ratio was 10:1). Hexane was added as a process control agent to prevent oxidation and

Table 1 Nominal composition (in at.\%) of the investigated powders

\begin{tabular}{llllll}
\hline Alloy designation & \multicolumn{3}{c}{ Composition of the alloy } & e/a ratio \\
\cline { 2 - 5 } & $\mathrm{Al}$ & $\mathrm{Cu}$ & $\mathrm{Fe}$ & $\mathrm{Si}$ & \\
\hline $\mathrm{Si} 0$ & 65 & 20 & 15 & - & 1.75 \\
$\mathrm{Si} 1$ & 58.5 & 18 & 13.5 & 10 & 1.98 \\
$\mathrm{Si} 2$ & 53.5 & 19.5 & 17 & 10 & 1.75 \\
\hline
\end{tabular}

eliminates tendency to ignite of the powder during milling. Milling was performed at a rotation speed $350 \mathrm{rpm}$ (revolution per minute) up to $20 \mathrm{~h}$ with intervals to cool down milled powders. The parameters of the milling process were chosen based on our experience in preparation of the ternary $\mathrm{Al}-\mathrm{Cu}-\mathrm{Fe}$ quasicrystalline powders [23, 24]. After milling, the selected powders were annealed at $800{ }^{\circ} \mathrm{C}$ for $4 \mathrm{~h}$ in quartz ampoules in vacuum. For the calculation of $\mathrm{e} / \mathrm{a}$, the nominal compositions were accepted, due to the results of the EDX microanalysis carried out in TEM showed similar chemical compositions of the milled powders as the initial values (see supplementary material).

The microstructure of the milled and heat treated powders was examined by X-ray diffraction (XRD) using D8 Discover Bruker diffractometer with Co K $\alpha$ filtered radiation $(\lambda=0.17903 \mathrm{~nm})$, scanning electron microscopy (SEM) using E-SEM XL and analytical transmission electron microscope (TEM) using FEI Tecnai $\mathrm{G}^{2}$ microscope at $200 \mathrm{kV}$ equipped with highangle annular dark-field scanning transmission electron microscopy detector (HAADF-STEM) combined with energy dispersive X-ray (EDX) EDAX microanalysis. For X-ray examination, powders were compacted in the mold to cylindrical form. Powders selected for SEM investigations were embedded in an epoxy resin, polished, and then, the specimen surface was coated with a conductive layer of carbon before examination. The TEM observations were made for the transparent region near the thin edge of the powder particles, which were placed on a carbon film supported by a nickel grid. The "ProcessDiffraction V-7.3.2Q" software developed by Labar [27] has been applied to measure interplanar spacing in the electron diffraction ring patterns.

\section{Results}

The phase evolution during the milling process was investigated by XRD measurements. Initial powders contained the mixture of constituent elements: $\mathrm{Al}$, $\mathrm{Cu}, \mathrm{Fe}$ and additionally $\mathrm{Si}$ in Si1 and Si2 powders. At the first stage of milling (after $3 \mathrm{~h}$ ), apart from the reflections of pure elements, Al-base phases started to form. For $\mathrm{Si} 0$ powder, the reflections of the cubic $\beta$ $\operatorname{Al}(\mathrm{Cu}, \mathrm{Fe})$ phase were observed, while weak reflections of the $\theta-\mathrm{Al}_{2} \mathrm{Cu}$ phase appeared in the quaternary compositions. 
Figure 1 Sets of XRD patterns of $\operatorname{Si} 0 \mathbf{a}, \operatorname{Si} 1 \mathbf{b}$ and $\mathrm{Si} 2 \mathrm{c}$ powders after 6,10 and $20 \mathrm{~h}$ of milling.
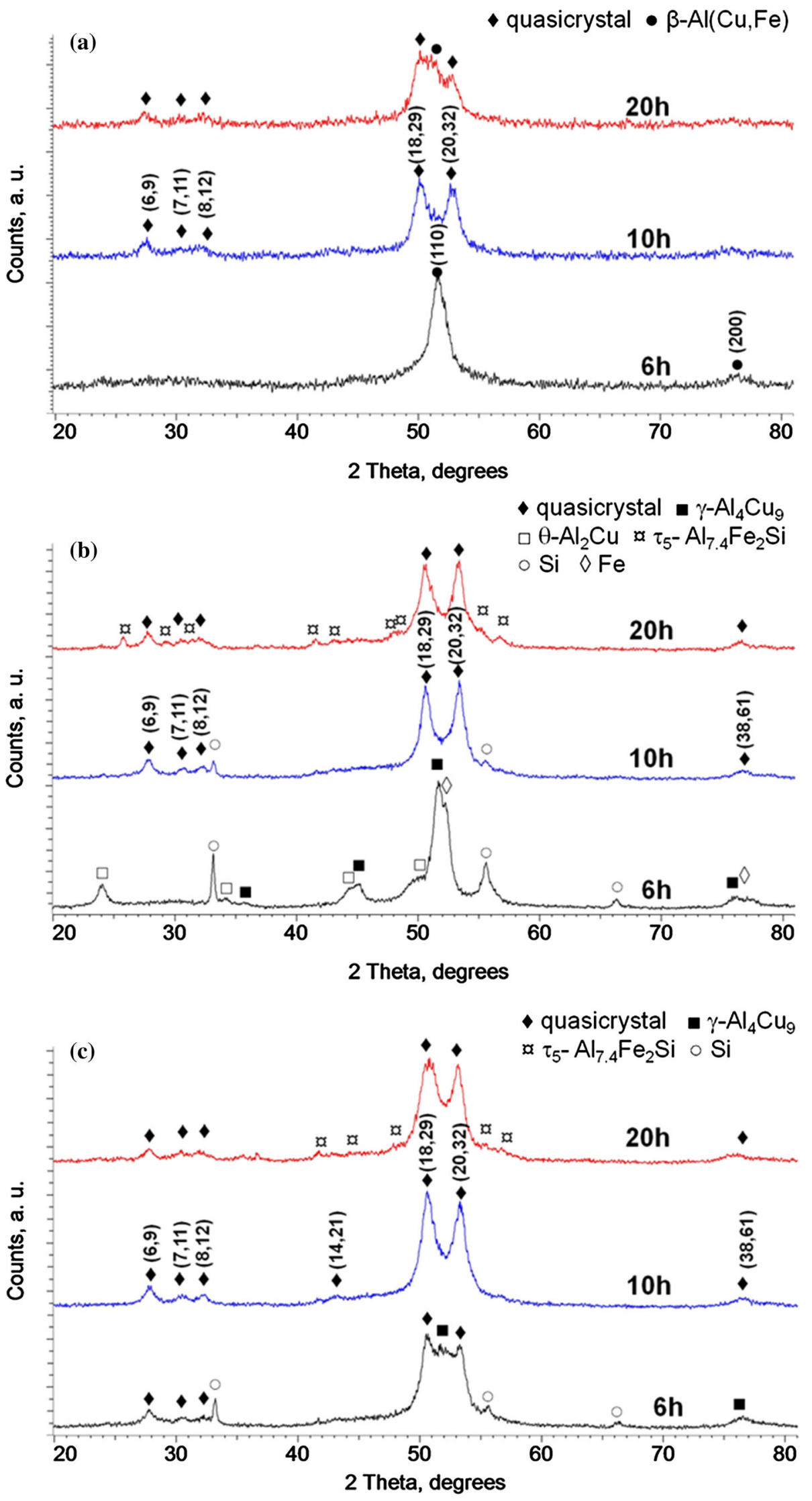
The sets of XRD patterns after 6, 10 and $20 \mathrm{~h}$ of milling for the examined compositions are presented in Fig. 1. After $6 \mathrm{~h}$ of milling, the reflections of constituent elements disappeared completely in the Si0 powder with simultaneous increase in the intensity of reflections of $\beta-\mathrm{Al}(\mathrm{Cu}, \mathrm{Fe})$ phase (Fig. 1a). The absence of (100) reflection indicates that the formed $\beta-\mathrm{Al}(\mathrm{Cu}, \mathrm{Fe})$ phase is disordered. For Si1 powder, the $\theta-\mathrm{Al}_{2} \mathrm{Cu}$ phase coexists with $\gamma-\mathrm{Al}_{4} \mathrm{Cu}_{9}$ phase, but the reflections of pure elements $\mathrm{Si}$ and $\mathrm{Fe}$ are still visible (Fig. 1b). The quasicrystalline i-phase dominates in the Si2 powder, accompanied by small amount of the $\gamma-\mathrm{Al}_{4} \mathrm{Cu}_{9}$ phase and Si (Fig. 1c). Ten hours of milling resulted in the formation of i-phase in all powders, although for the Si1 powder the small amount of $\mathrm{Si}$ was also detected (Fig. 1b). The diffraction peaks of the i-phase were indexed using Cahn's scheme as a face-centered icosahedral quasicrystal (the superlattice reflection $(7,11)$ is visible) $[36,37]$. It can be seen that reflections of the i-phase in both Si-containing powders exhibit higher intensity compared to reference $\mathrm{Si} 0$ powder. Extending the milling time to $20 \mathrm{~h}$ led to reduction of the phase fraction of the i-phase and the formation of a disordered $\beta-\mathrm{Al}(\mathrm{Cu}, \mathrm{Fe})$ phase in $\mathrm{Si} 0$ powder (Fig. 1a), while the i-phase was still dominant in the Si1 and Si2 with only a trace amount of the hexagonal $\tau_{5}-\mathrm{Al}_{7.4} \mathrm{Fe}_{2} \mathrm{Si}$ phase (Fig. $1 \mathrm{~b}, \mathrm{c}$ ). The identified phases and their lattice parameters are presented in Table 2. The powders after $10 \mathrm{~h}$ of milling were selected for further microstructural investigations and subsequent heat treatment because of the i-phase presence in all the examined compositions.

The SEM-BSE microstructures of the cross sections of the powders after $10 \mathrm{~h}$ of milling are given in Fig. 2. All powders contained particles with maximum dimension below $100 \mu \mathrm{m}$; however, most of the particles had a size of $10-20 \mu \mathrm{m}$. The defragmentation of the particles was not finished and a lot of cracks can be seen at higher magnification in Fig. $2 \mathrm{~d}-$ f. The cross sections of particles did not show differences in contrast, which may indicate their almost homogeneous structure.

The presence of the i-phase in the form of small crystallites was observed by TEM in all investigated powders. As an example, the bright (BF) and dark (DF) field images of the Si2 powder are shown in Fig. 3. The nanocrystallites of the i-phase with a diameter of the 10-20 $\mathrm{nm}$ are clearly visible in the DF microstructure. The selected area electron diffraction pattern (SADP) obtained from the area presented in Fig. 3a, b contains reflections lying along DebyeScherrer rings; measured $\mathrm{d}$-spacing values were indexed as the quasicrystalline i-phase (unlike the XRD diffraction, and the superlattice reflection $(7,11)$ was not detected may be due to the local disordering of the i-phase).

The stability of the quasicrystalline phase during annealing at $800{ }^{\circ} \mathrm{C}$ for $4 \mathrm{~h}$ in the powders milled for $10 \mathrm{~h}$ was examined by X-ray diffraction (Fig. 4). For the Si0 powder, in addition to the quasicrystalline phase, which was present in the as-milled powder,

Table 2 The phases identified in the Si0, Si1 and Si2 powders after milling and after annealing

\begin{tabular}{|c|c|c|c|}
\hline Phase & Structure, space group & Lattice parameters $[\mathrm{nm}, \mathrm{deg}]$ & Reference \\
\hline (Al) & Cubic, Fm-3 m & $\mathrm{a}=0.4049$ & {$[28]$} \\
\hline$(\mathrm{Cu})$ & Cubic, Fm-3 m & $\mathrm{a}=0.3614$ & {$[28]$} \\
\hline$\alpha-\mathrm{Fe}$ & Cubic, Im-3 m & $\mathrm{a}=0.2866$ & {$[28]$} \\
\hline$(\mathrm{Si})$ & Cubic, Fd-3 m & $\mathrm{a}=0.5431$ & {$[28]$} \\
\hline$\beta-\mathrm{Al}(\mathrm{Cu}, \mathrm{Fe})$ & Cubic, $\mathrm{Pm} 3 \mathrm{~m}$ & $\mathrm{a}=0.2941$ & {$[29]$} \\
\hline$\theta-\mathrm{Al}_{2} \mathrm{Cu}$ & Tetragonal, I4/mcm & $\mathrm{a}=0.6067, \mathrm{c}=0.4877$ & {$[30]$} \\
\hline$\gamma-\mathrm{Al}_{4} \mathrm{Cu}_{9}$ & Cubic, P-43 m & $\mathrm{a}=0.8703$ & [31] \\
\hline $\mathrm{i}-\mathrm{Al}_{65} \mathrm{Cu}_{20} \mathrm{Fe}_{15}$ & Icosahedral phase & - & {$[32]$} \\
\hline$\tau_{5}-\mathrm{Al}_{7.4} \mathrm{Fe}_{2} \mathrm{Si}$ & hexagonal & $\mathrm{a}=1.234 \mathrm{~nm}, \mathrm{c}=2.621 \mathrm{~nm}$ & {$[33]$} \\
\hline$\lambda-\mathrm{Al}_{13} \mathrm{Fe}_{4}$ & Monoclinic, $\mathrm{C} 2 / \mathrm{m}$ & $\mathrm{a}=1.5492, \mathrm{~b}=0.8078, \mathrm{c}=1.2471, \beta=107.69^{\circ}$ & [34] \\
\hline$\tau_{1}-\mathrm{Al}_{2} \mathrm{Fe}_{3} \mathrm{Si}_{3}$ & Triclinic, $\mathrm{P}-1$ & $\begin{array}{l}\mathrm{a}=0.4651, \mathrm{~b}=0.6326, \mathrm{c}=0.7499, \alpha=101.37, \beta=105.92 \\
\quad \gamma=101.24\end{array}$ & [35] \\
\hline $\mathrm{Al}_{55} \mathrm{Si}_{7} \mathrm{Cu}_{25.5} \mathrm{Fe}_{12.5}$ & $\begin{array}{l}\text { Cubic, } \mathrm{Pm}-31 / 1 \\
\text { approximant }\end{array}$ & $\mathrm{a}=1.2321$ & {$[17]$} \\
\hline
\end{tabular}



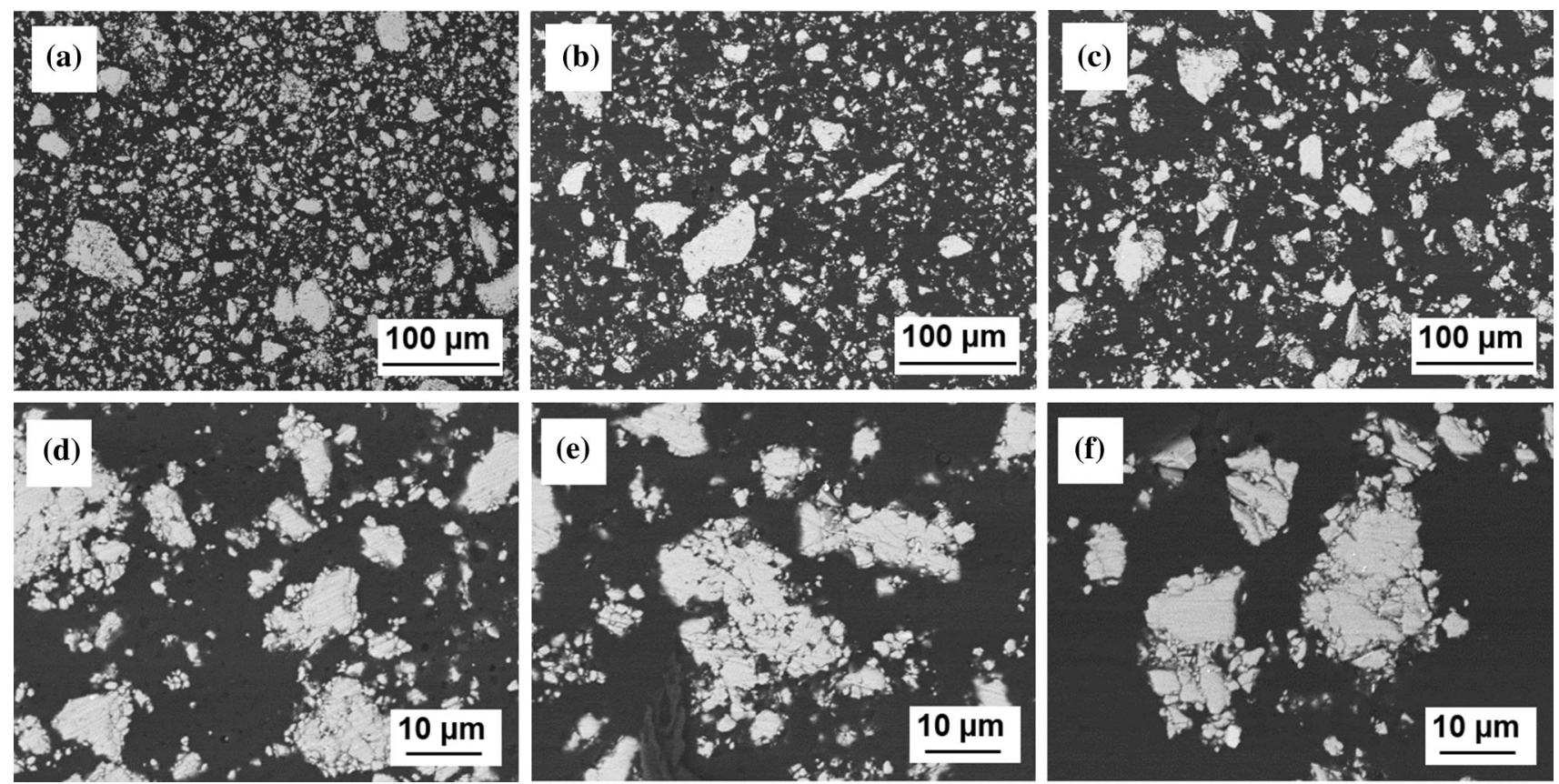

Figure 2 SEM-BSE microstructures of the cross section of the Si0 (a, d), Si1 (b, e) and Si2 (c, f) powders after $10 \mathrm{~h}$ of milling.
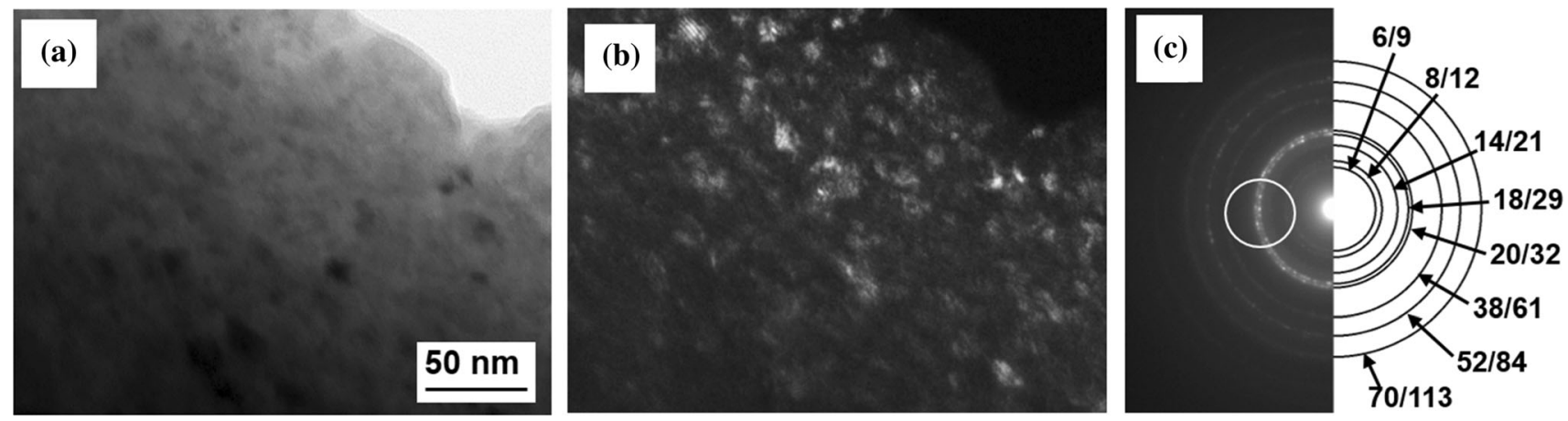

Figure 3 TEM a bright- and $\mathbf{b}$ dark-field microstructures and $\mathbf{c}$ corresponding SADP (the position of the objective aperture for DF image is marked) of the $\mathrm{Si} 2$ powder milled for $10 \mathrm{~h}$.

the ordered $\beta-\mathrm{Al}(\mathrm{Cu}, \mathrm{Fe})$ and $\lambda-\mathrm{Al}_{13} \mathrm{Fe}_{4}$ phases were identified. In the case of Si1 powder, i-phase transformed completely during annealing into the cubic $\alpha$ $\mathrm{Al}_{55} \mathrm{Si}_{7} \mathrm{Cu}_{25.5} \mathrm{Fe}_{12.5}$ approximant. The $\mathrm{Si} 2$ powder contained the mixture of the i-phase and the ordered $\beta-\mathrm{Al}(\mathrm{Cu}, \mathrm{Fe})$ as dominant phases, and traces of triclinic $\tau_{1}-\mathrm{Al}_{2} \mathrm{Fe}_{3} \mathrm{Si}_{3}$ phase and the $\alpha-\mathrm{Al}_{55} \mathrm{Si}_{7} \mathrm{Cu}_{25.5} \mathrm{Fe}_{12.5}$ approximant.

The Si1 powder particles consisted of randomly distributed crystallites of 100-300 nm, what means that the size of the crystallites after annealing increased significantly (Fig. 5). The corresponding SADP was in the form of rings that can be identified as the $\alpha-\mathrm{Al}_{55} \mathrm{Si}_{7} \mathrm{Cu}_{25.5} \mathrm{Fe}_{12.5}$ approximant, confirming the $\mathrm{XRD}$ results.
In the Si2 powder, the growth of the crystallites during annealing was not as significant as in the case of the Si1 powder. Grain growth up to about $100 \mathrm{~nm}$ could be seen in the TEM bright- and dark-field microstructures presented in Fig. 6a, b. The corresponding SADP (Fig. 6c) contains reflections of the ordered $\beta-\mathrm{Al}(\mathrm{Cu}, \mathrm{Fe})$, which was identified in the XRD pattern as one of the prevailing phases (Fig. 4). The weaker reflections of the i-phase, which overlap with or lie close to reflections of $\beta-\mathrm{Al}(\mathrm{Cu}, \mathrm{Fe})$ phase, are also visible in the presented SADP. 
Figure 4 Set of XRD patterns

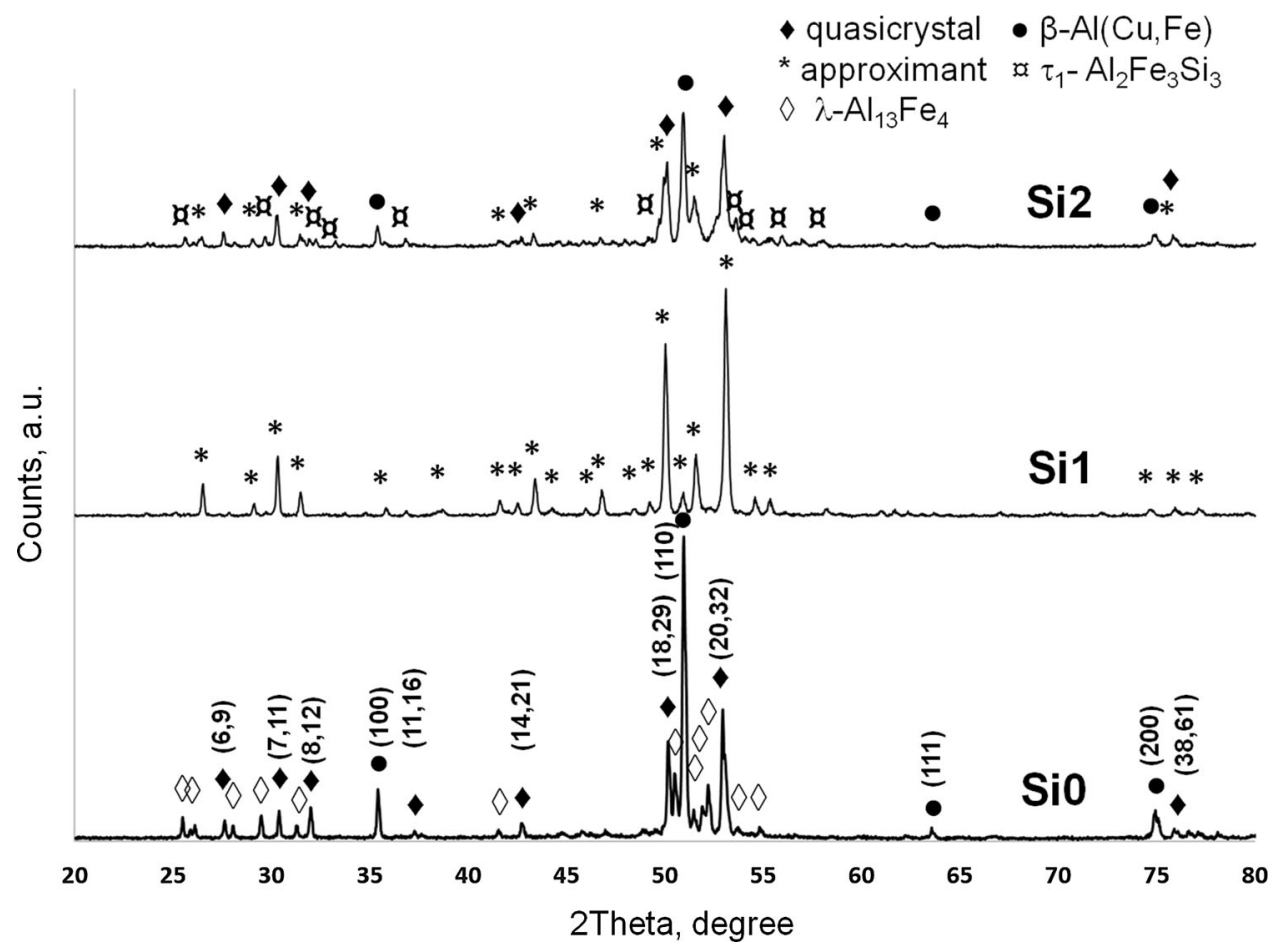
of $\mathrm{Si} 0, \mathrm{Si} 1$ and $\mathrm{Si} 2$ powders after $10 \mathrm{~h}$ of milling and subsequent annealing at $800{ }^{\circ} \mathrm{C}$ for $4 \mathrm{~h}$.
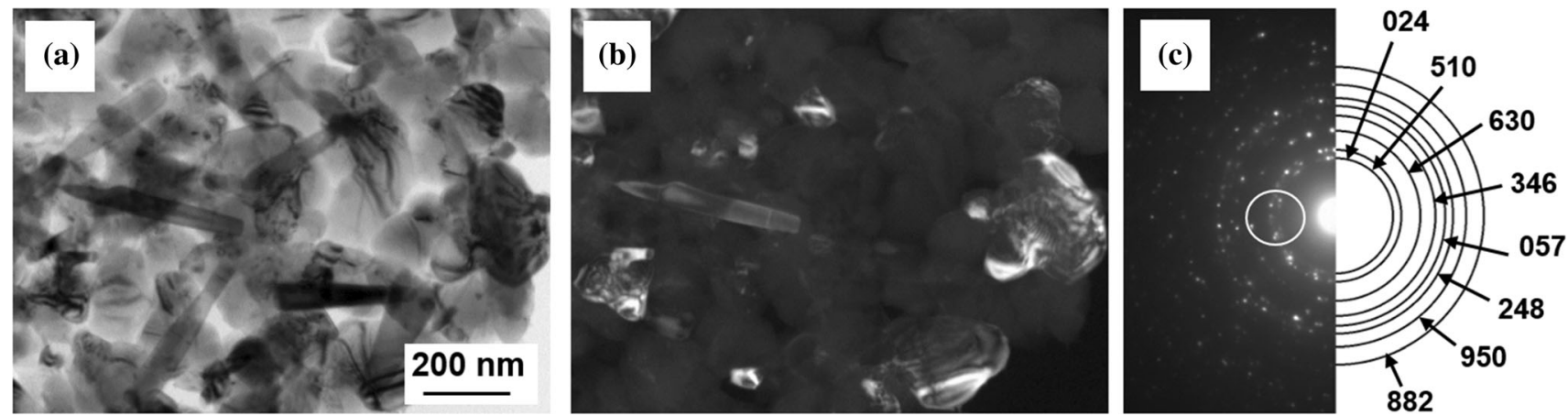

Figure 5 TEM a bright- and $\mathbf{b}$ dark-field microstructure and $\mathbf{c}$ corresponding SADP (the position of the objective aperture for DF image is marked) of the Sil powder milled for $10 \mathrm{~h}$ and annealing at $800{ }^{\circ} \mathrm{C}$ for $4 \mathrm{~h}$.

(a)

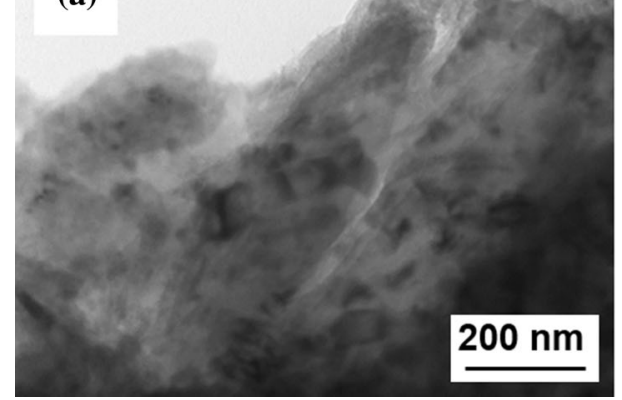

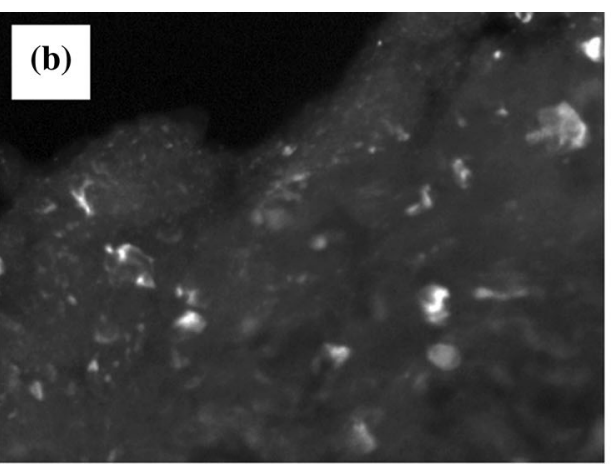

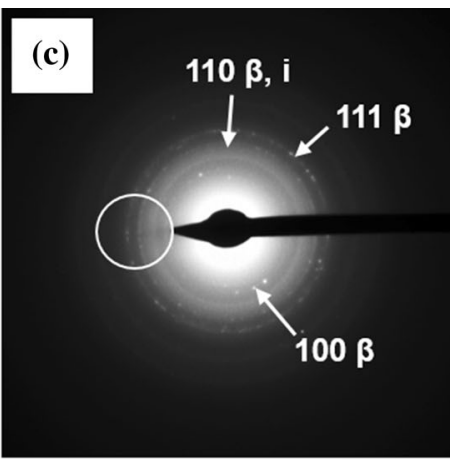

Figure 6 TEM $\mathbf{a}$ bright- and $\mathbf{b}$ dark-field microstructures and $\mathbf{c}$ corresponding SADP (the position of the objective aperture for DF image is marked) of the Si2 powders milled for $10 \mathrm{~h}$ and annealing at $800{ }^{\circ} \mathrm{C}$ for $4 \mathrm{~h}$. 


\section{Discussion}

The presented studies have shown that mechanical alloying is a method that can lead to the formation of face-centered icosahedral quasicrystalline phase for all investigated powder compositions. In the case of ternary $\mathrm{Al}-\mathrm{Cu}-\mathrm{Fe}$ powder, the i-phase has been observed in milled powders of similar composition [21-23, 38-40]. It was also revealed, as in our research, that the i-phase after a longer milling time transformed into the disordered cubic $\beta-\mathrm{Al}(\mathrm{Cu}, \mathrm{Fe})$ phase. The same transition was also found in the Al$\mathrm{Cu}-\mathrm{Fe}[41,42]$ and $\mathrm{Sn}$ reinforced $\mathrm{Al}-\mathrm{Cu}-\mathrm{Fe}$ [43] powders during ball milling of a cast, annealed and crushed alloy containing the stable i-phase, which after milling, transformed into the cubic $\beta-\mathrm{Al}(\mathrm{Cu}, \mathrm{Fe})$ phase. The transition was explained by occurrence of a quasilattice strain introduced during milling (phase distortion and phonon distortion component), when the grain size of the quasicrystalline phase decreased to $\sim 10 \mathrm{~nm}$.

In both quaternary $\mathrm{Al}-\mathrm{Cu}-\mathrm{Fe}-\mathrm{Si}$ powders, despite the identical silicon amount of 10 at.\%, the formation of a quasicrystalline phase during milling took place in a different way. The i-phase started to form in the $\mathrm{Si} 2-\mathrm{Al}_{53.5} \mathrm{Cu}_{19.5} \mathrm{Fe}_{17} \mathrm{Si}_{10}$ powder $(\mathrm{e} / \mathrm{a}=1.75)$ faster than for the $\mathrm{Sil}_{-} \mathrm{Al}_{58.5} \mathrm{Cu}_{18} \mathrm{Fe}_{13.5} \mathrm{Si}_{10}$ powder (e/ $\mathrm{a}=1.98$ ) and pronounced reflections of this phase coexists with small amount of silicon and $\mathrm{Al}_{4} \mathrm{Cu}_{9}$ phase after $6 \mathrm{~h}$ of milling. After the same milling time, the Sil powder contained, apart from pure elements $\mathrm{Si}$ and $\mathrm{Fe}$, the $\mathrm{Al}_{2} \mathrm{Cu}$ and $\mathrm{Al}_{4} \mathrm{Cu}_{9}$ phases, while the i-phase was not observed. The formation of binary phases containing $\mathrm{Al}$ and $\mathrm{Cu}$ at initial stage of milling is related to the higher diffusion coefficient of $\mathrm{Cu}$ in aluminum compared to $\mathrm{Si}$ and $\mathrm{Fe}$.

A quasicrystalline structure has been observed after $10 \mathrm{~h}$ of milling in both Si1 and Si2 compositions. For the Si2 powder, the i-phase was detected as a single phase, while for the Si1, it was accompanied by a small amount of silicon. This can be explained by the fact that $\mathrm{Al}$ content in $\mathrm{Si1}$ powder was higher than that in $\mathrm{Si} 2$, and since $\mathrm{Si}$ atoms replaced $\mathrm{Al}$ atoms, only a part of $\mathrm{Si}$ was consumed to form the quasicrystalline phase for this composition (the $\mathrm{Al}$ : $\mathrm{Cu}$ : Fe ratio in Si1 corresponds to the i-phase). It was also found that the i-phase in the Si1 powder appeared after a shorter milling time compared to the results obtained by Murty et.al. [13], where $30 \mathrm{~h}$ was needed to form the quasicrystalline phase (together with $\beta-\mathrm{Al}(\mathrm{Cu}$,
Fe)) for the same powder composition. This may be due to differences in milling conditions, in particular high milling speed and using WC milling media in our experiments, which led to an increase in the total energy transferred to the powder during milling process.

SEM and TEM observations have shown that the i-phase was visible in the form of small crystallites in all investigated powders after $10 \mathrm{~h}$ of milling. Similar size and distribution of the crystallites of the i-phase inside the powder particles was reported by Murty et al. [13] in the sample after $40 \mathrm{~h}$ of milling for composition analogous to Sil. Nanocrystallites of the i-phase are also observed in the previous studies of the mechanically milled powder [11, 24, 44, 45].

The quasicrystalline phase is not stable and prolonged milling resulted in its partial transformation. In contrast to the $\mathrm{Si} 0$ alloy, where the $\beta-\mathrm{Al}(\mathrm{Cu}, \mathrm{Fe})$ single phase appeared, a small fraction of $\tau_{5}-\mathrm{Al}_{7.4}$ $\mathrm{Fe}_{2} \mathrm{Si}$ phase except dominated the i-phase was identified in both Si-containing alloys. It should be noted that the face-centered icosahedral quasicrystalline phase was detected through the whole milling process. The traces of the $\tau_{5}-\mathrm{Al}_{7.4} \mathrm{Fe}_{2} \mathrm{Si}$ phase, one of a ternary $\tau$-type phases enriched in $\mathrm{Fe}$ and $\mathrm{Si}$ [46], has been observed in multilayered $\mathrm{Al} / \mathrm{Cu} / \mathrm{Fe}$ thin films deposited onto $\mathrm{Si}$ substrate in the Al-deficient samples, together with the dominating $\alpha-\mathrm{Al}_{55} \mathrm{Si}_{7} \mathrm{Cu}_{25.5-}$ $\mathrm{Fe}_{12.5}$ approximant [47].

The quasicrystalline i-phase identified in all investigated powders milled for $10 \mathrm{~h}$ underwent different transformations during annealing at $800{ }^{\circ} \mathrm{C}$ for $4 \mathrm{~h}$ to form various phases. For the ternary Si0$\mathrm{Al}_{65} \mathrm{Cu}_{20} \mathrm{Fe}_{15}$ powder, the dominant ordered $\beta-\mathrm{Al}(\mathrm{Cu}$, $\mathrm{Fe}$ ) phase is accompanied by the $\mathrm{i}$-phase and small amount of the $\lambda-\mathrm{Al}_{13} \mathrm{Fe}_{4}$. In the XRD pattern, the strong and sharp reflections of the both main phases are clearly visible, due to the increased size of the crystallites compared to the as-milled state. This result is consistent with our previous experiments for an annealed $\mathrm{Al}-\mathrm{Cu}-\mathrm{Fe}$ powder, which also contained the $\beta-\mathrm{Al}(\mathrm{Cu}, \mathrm{Fe})$ and the i-phase, regardless of the phases identified in the powders after milling [24]. Similar, two-phase microstructure of annealed Al$\mathrm{Cu}-\mathrm{Fe}$ powders has also been reported by other researchers, e.g., [44, 48, 49].

The conditions of the milling process and the milling time influence the phase composition of as-milled powders, and thus are of decisive importance for the formation of the quasicrystalline phase after 
annealing. The synthesis of a powder with a high volume fraction of the quasicrystal phase could be achieved by combination of a short milling time and subsequent annealing [19, 44, 49-51]. The formation of the quasicrystalline phase in $\mathrm{Al}-\mathrm{Cu}-\mathrm{Fe}$ powders containing $\beta$ and $\theta$ phases in as-milled state after nonisothermal annealing above $750{ }^{\circ} \mathrm{C}$ was reported by Nicula et al. [50]. Salimon et al. [51] showed that the as-milled powder consisting of a mixture of solid solutions of starting elements and the $\mathrm{Al}_{2} \mathrm{Cu}$ phase transformed into an almost single icosahedral quasicrystalline phase after annealing at $700{ }^{\circ} \mathrm{C}$. Ali et al. [52] studied the phase evolution during milling and subsequent annealing of the quasicrystalline phase and concluded that the formation of the ordered $\beta$ $\mathrm{Al}(\mathrm{Cu}, \mathrm{Fe})$ phase was promoted with increasing milling time. The stored internal energy reduced the activation barrier for nucleation of the crystalline $\beta$ $\operatorname{Al}(\mathrm{Cu}, \mathrm{Fe})$ phase in the icosahedral structure (samples milled for longer time require lower thermal energy for transformation).

The i-phase was partially preserved also in Si2$\mathrm{Al}_{53.5} \mathrm{Cu}_{19.5} \mathrm{Fe}_{17} \mathrm{Si}_{10}$ powder, although the volume fraction of the ordered $\beta-\mathrm{Al}(\mathrm{Cu}, \mathrm{Fe})$ was lower compared to the Si0. It should be noted that the calculated e/a ratio for both powders is identical and equal 1.75, what may be the reason for similar phase composition after annealing (Si-containing phases, $\alpha-\mathrm{Al}_{55} \mathrm{Si}_{7-}$ $\mathrm{Cu}_{25.5} \mathrm{Fe}_{12.5}$ approximant and $\mathrm{Al}_{2} \mathrm{Fe}_{3} \mathrm{Si}_{3}$ phase, replaced $\lambda-\mathrm{Al}_{13} \mathrm{Fe}_{4}$ phase in $\mathrm{Si} 2$ powder). In the case of the $\mathrm{Si1}-\mathrm{Al}_{58.5} \mathrm{Cu}_{18} \mathrm{Fe}_{13.5} \mathrm{Si}_{10}$ powder, the i-phase completely transforms during annealing to the cubic $\alpha-\mathrm{Al}_{55} \mathrm{Si}_{7} \mathrm{Cu}_{25.5} \mathrm{Fe}_{12.5}$ approximant, which is associated with significant increase of the grain size up to about $300 \mathrm{~nm}$. The transformation of the quasicrystalline phase into the cubic approximant was also found in the gas atomized powder of a similar composition $\left(\mathrm{Al}_{57} \mathrm{Cu}_{17.75} \mathrm{Fe}_{14.75} \mathrm{Si}_{10.5}\right)$ after heating to a temperature above $600{ }^{\circ} \mathrm{C}$ [53]. A different result for the powder of identical composition was obtained by Murty et.al. [13], wherein a mixture of the i-phase and the $\beta-\mathrm{Al}(\mathrm{Cu}, \mathrm{Fe})$ was obtained during annealing at $600{ }^{\circ} \mathrm{C}$ (it should be mentioned that the as-milled powder before annealing also contained these phases). The different phase composition obtained after milling as well as after annealing can be caused by different parameters used during milling, as well as different annealing temperature.

Based on the results obtained, it can be concluded, that addition of 10 at.\% of $\mathrm{Si}$, irrespective of the mutual content of other components and the e/a ratio, has a positive effect on the formation of the icosahedral phase in Al-Cu-Fe powders produced by mechanical alloying. The quasicrystalline phase in both Si1 and Si2 powders was more stable and retained after a longer milling time as compared to the reduced volume fraction of this phase in favor of the $\beta-\mathrm{Al}(\mathrm{Cu}, \mathrm{Fe})$ phase in the reference ternary Si0 alloy. These results may be important for application of the powders with a quasicrystalline structure. Due to their high hardness and brittleness, these powdered materials can be used, for example, as a reinforcement in composites. The stability of the quasicrystalline phase is highly dependent on the e/a ratio in the powders during annealing. It was found that i-phase in the Si2 and Si0 powders, with the e/a ratio equal to 1.75 , is partially preserved, while the Si1 powder with e/a $=1.98$ was completely transformed to the cubic approximant.

\section{Conclusions}

The quasicrystalline icosahedral i-phase formed in the $\mathrm{Al}_{58.5} \mathrm{Cu}_{18} \mathrm{Fe}_{13.5} \mathrm{Si}_{10}, \mathrm{Al}_{53.5} \mathrm{Cu}_{19.5} \mathrm{Fe}_{17} \mathrm{Si}_{10}$ and the reference $\mathrm{Al}_{65} \mathrm{Cu}_{20} \mathrm{Fe}_{15}$ mechanically alloyed powders after $10 \mathrm{~h}$ of milling at the speed of $350 \mathrm{rpm}$ and using WC milling media. Particles of the powder consisted the fine 10-20 nm crystallites of the i-phase for all investigated compositions. Addition of Si stabilized the quasicrystalline phase being dominant after extended milling time, contrary to the reference ternary powder, which apart of quasicrystalline phase contained the cubic $\beta-\mathrm{Al}(\mathrm{Cu}, \mathrm{Fe})$.

Annealing of the powders milled $10 \mathrm{~h}$ at $800{ }^{\circ} \mathrm{C}$ for $4 \mathrm{~h}$ maintained partially the i-phase in $\mathrm{Al}_{65} \mathrm{Cu}_{20} \mathrm{Fe}_{15}$ and $\mathrm{Al}_{53.5} \mathrm{Cu}_{19.5} \mathrm{Fe}_{17} \mathrm{Si}_{10}$ powders (e/a ratio was 1.75 for both compositions) accompanied by an increase of crystallites sizes up to $100 \mathrm{~nm}$. The i-phase coexisted with $\beta-\mathrm{Al}(\mathrm{Cu}, \mathrm{Fe})$ and small fraction of $\mathrm{Al}_{13} \mathrm{Fe}_{4}$ or $\alpha-$ $\mathrm{Al}_{55} \mathrm{Si}_{7} \mathrm{Cu}_{25.5} \mathrm{Fe}_{12.5}$ and $\tau_{1}-\mathrm{Al}_{2} \mathrm{Fe}_{3} \mathrm{Si}_{3}$ phases in $\mathrm{Al}_{65-}$ $\mathrm{Cu}_{20} \mathrm{Fe}_{15}$ and $\mathrm{Al}_{53.5} \mathrm{Cu}_{19.5} \mathrm{Fe}_{17} \mathrm{Si}_{10}$, respectively. For the $\mathrm{Al}_{58.5} \mathrm{Cu}_{18} \mathrm{Fe}_{13.5} \mathrm{Si}_{10}$ powders $(\mathrm{e} / \mathrm{a}=1.98)$ the annealing led to the complete i-phase transformation to the cubic $\alpha-\mathrm{Al}_{55} \mathrm{Si}_{7} \mathrm{Cu}_{25.5} \mathrm{Fe}_{12.5}$ approximant in the form of $100-300 \mathrm{~nm}$ crystals. 


\section{Acknowledgements}

Financial support from the Polish National Science Centre NCN, research projects no 2015/19/N/ST8/ 01036 is gratefully acknowledged. Samples were examined in the Accredited Testing Laboratories at the Institute of Metallurgy and Materials Science of the Polish Academy of Sciences in Cracow.

\section{Declarations}

Conflict of interest There are no conflicts of interest to declare.

Supplementary Information: The online version of this article https://doi.org/10.1007/s10853-021-0596 3-6.

Open Access This article is licensed under a Creative Commons Attribution 4.0 International License, which permits use, sharing, adaptation, distribution and reproduction in any medium or format, as long as you give appropriate credit to the original author(s) and the source, provide a link to the Creative Commons licence, and indicate if changes were made. The images or other third party material in this article are included in the article's Creative Commons licence, unless indicated otherwise in a credit line to the material. If material is not included in the article's Creative Commons licence and your intended use is not permitted by statutory regulation or exceeds the permitted use, you will need to obtain permission directly from the copyright holder. To view a copy of this licence, visit http://creativecommons.org/licen ses/by $/ 4.0 /$.

Supplementary Information: The online version of this article https://doi.org/10.1007/s10853-021-0596 3-6.

\section{References}

[1] Tsai AP, Inoue A, Masumoto T (1987) A stable quasicrystal in Al-Cu-Fe system. Jpn J Appl Phys 26:L1505-L1507

[2] Huttunen-Saarivirta E (2004) Microstructure, fabrication and properties of quasicrystalline $\mathrm{Al}-\mathrm{Cu}-\mathrm{Fe}$ alloys: a review. J Alloys Compd 363:150-174

[3] Dubois JM (2005) Useful quasicrystals. World Scientific, Singapore
[4] Barthes-Labrousse MG, Dubois JM (2008) Quasicrystals and complex metallic alloys: trends for potential applications. Philos Mag 88:2217-2225

[5] Dubois JM (2012) Properties- and applications of quasicrystals and complex metallic alloys. Chem Soc Rev 41:6760-6777

[6] Raghavan V (2005) Al-Cu-Fe (Aluminum-Copper-Iron). J Phase Equilib Diffus 26:59-64

[7] Raghavan V (2010) Al-Cu-Fe (Aluminum-Copper-Iron). J Phase Equilib Diffus 31:449-452

[8] Zhu L, Soto-Medina S, Cuadrado-Castillo W, Hennig RG, Manuel MV (2019) New experimental studies on the phase diagram of the $\mathrm{Al}-\mathrm{Cu}-\mathrm{Fe}$ quasicrystal-forming system. Mater Des 185:108186

[9] Tsai AP, Inoue A, Masumoto T (1989) Effects of preparation conditions and additional elements on phason strains in stable icosahedral quasicrystals in $\mathrm{Al}-\mathrm{Cu}-\mathrm{Fe}$ systems. J Mater Sci Lett 8:470-472

[10] Lee SM, Kim BH, Kim SH, Fleury E, Kim WT, Kim DH (2000) Effect of $\mathrm{Si}$ addition on the formability of the icosahedral quasicrystalline phase in an $\mathrm{Al}_{65} \mathrm{Cu}_{20} \mathrm{Fe}_{15}$ alloy. Mater Sci Eng 294-296:93-98

[11] Wang Y, Zhang Z, Geng H, Yang Z (2006) Formation of the icosahedral quasicrystalline phase in a rapidly solidified $\mathrm{Al}_{52} \mathrm{Cu}_{25.5} \mathrm{Fe}_{12.5} \mathrm{Si}_{10}$ alloy. Mater Charact 56:200-207

[12] Kim KB, Kim SH, Kim WT, Kim DH, Hong KT (2001) Structural evolution during heat treatment of mechanically alloyed $\mathrm{Al}-\mathrm{Cu}-\mathrm{Fe}-(\mathrm{Si})$ alloys. Mater Sci Eng A 304-306:822-829

[13] Murty BS, Barua P, Srinivas V, Schurack F, Eckert J (2004) Synthesis of $\left(\mathrm{Al}_{65} \mathrm{Cu}_{20} \mathrm{Fe}_{15}\right)_{100-\mathrm{x}} \mathrm{Si}_{\mathrm{x}}$ quasicrystalline alloys by mechanical alloying. J Non-Cryst Solids 334-335:44-47

[14] Sukhova OV, Ustinova KV (2019) The effect of cooling rates on phase composition of quasicrystalline $\mathrm{Al}-\mathrm{Cu}-\mathrm{Fe}$ alloys doped with Si and B. Funct Mater 26:495-506

[15] Quivy A, Quiquandon M, Calvayrac Y, Faudot F, Gratias D, Berger C, Brand RA, Simonet V, Hippert F (1996) A cubic approximant of the icosahedral phase in the (Al-Si) $-\mathrm{Cu}-\mathrm{Fe}$ system. J Phys Cond Mat 8:4223-4234

[16] Takeuchi T, Yamada H, Takata M, Nakata T, Tanaka N, Mizutani U (2000) Atomic structure of the Al-Cu-Fe-Si 1/1-cubic approximant. Mater Sci Eng 294-296:340-344

[17] Stadnik ZM, Takeuchi T, Tanaka N, Mizutani U (2003) Structural, Mossbauer, and transport studies of the icosahedral quasicrystals A155Si7Cu25.5Fe12.5, A162.5Cu24.5Fe13 and the crystalline 1/1 approximant $\mathrm{A} 155 \mathrm{Si} 7 \mathrm{Cu} 25.5 \mathrm{Fe} 12.5$. J Phys Condens Matter 15:6365-6380

[18] Karaköse E, Keskin M (2012) Microstructure properties and microhardness of rapidly solidified A164Cu20Fe12Si4 quasicrystal alloy. Met Mater Int 18:257-263 
[19] Salimon AI, Korsunsky AM, Shelekhov EV, Sviridova TA, Kaloshkin SA, Tcherdyntsev VS, Baldokhin YV (2001) Crystallochemical aspects of solid state reactions in mechanically alloyed $\mathrm{Al}-\mathrm{Cu}-\mathrm{Fe}$ quasicrystalline powders. Acta Mater 49:1821-1833

[20] Schurack F, Eckert J, Schultz L (2003) Synthesis and mechanical properties of mechanically alloyed $\mathrm{Al}-\mathrm{Cu}-\mathrm{Fe}$ quasicrystalline composites. Phil Mag 83:1287-1305

[21] Bokhonov BB (2008) Mechanical alloying and self-propagating high-temperature synthesis of stable icosahedral quasicrystals. J Alloys Compd 461:150-153

[22] Novák P, Kubatík T, Vystrcil J, Hendrych R, Kríz J, Mlynár J, Vojtech D (2014) Powder metallurgy preparation of Al$\mathrm{Cu}-\mathrm{Fe}$ quasicrystals using mechanical alloying and Spark Plasma Sintering. Intermetallics 52:131-137

[23] Mitka M, Lityńska-Dobrzyńska L, Góral A, Maziarz W (2014) Influence of mechanical alloying parameters on phase formation in $\mathrm{Al}-\mathrm{Cu}-\mathrm{Fe}$ powder. Acta Phys Polonica A 126(2014):894-897

[24] Mitka M, Góral A, Rogal Ł, Lityńska-Dobrzynska L (2015) Microstructure of mechanically alloyed and annealed A162Cu25.5Fe12.5 powder. J Alloys Compd 653:47-53

[25] Tsai AP, Inoue A, Masumoto T (1989) Icosahedral, decagonal and amorphous phases in Al-Cu-M (M=Transition Metal) system. Mater Trans 30:666-676

[26] Trambly de Laissardière G, Nguyen-Manh D, Mayou D (2005) Electronic structure of complex Hume-Rothery phases and quasicrystals in transition metal aluminides. Prog Mater Sci 50:679-788

[27] Lábár JL (2008) Electron diffraction based analysis of phase fractions and textures in nanocrystalline thin films; Part I: principles. Microsc Microanal 14:287-295

[28] Villars P, Calvert LD (1991) Pearson's handbook of crystallographic data for intermediate phases, 2nd edn. ASM International, Materials Park, $\mathrm{OH}$

[29] Chen HL, Du Y, Xu H, Xiong W (2009) Experimental investigation and thermodynamic modeling of the ternary $\mathrm{Al}-\mathrm{Cu}-\mathrm{Fe}$ system. J Mater Res 24:3154-3164

[30] Meetsma A, De Boer JL, Van Smaalen S (1989) Refinement of the crystal structure of tetragonal $\mathrm{Al}_{2} \mathrm{Cu}$. J Solid State Chem 83:370-372

[31] Kisi EH, Browne JD (1991) Ordering and structural vacancies in non-stoichiometric $\mathrm{Cu}-\mathrm{Al} \gamma$ brasses. Acta Crystallogr B 47:835-843

[32] Ishimasa T, Fukano Y, Tsuchimori M (1988) Quasicrystal structure in $\mathrm{Al}-\mathrm{Cu}-\mathrm{Fe}$ annealed alloy. Philos Mag 58:157-165

[33] Roger J, Bosselet F, Viala J (2011) X-rays structural analysis and thermal stability studies of the ternary compound $\alpha$ AlFeSi. J Solid State Chem 184:1120-1128
[34] Ellner M (1995) Polymorphic phase transformation of $\mathrm{Fe}_{4-}$ $\mathrm{Al}_{13}$ causing multiple twinning with decagonal pseudosymmetry. Acta Crystallogr B 51:31-36

[35] Yanson TI, Manyako MB, Bodak OI, German NV, Zarechnyuk OS, Cerny R, Pacheco JV, Yvon K (1996) Triclinic $\mathrm{Fe}_{3} \mathrm{Al}_{2} \mathrm{Si}_{3}$ and orthorhombic $\mathrm{Fe}_{3} \mathrm{Al}_{2} \mathrm{Si}_{4}$ with new structure types. Acta Crystallogr C 52:2964-2967

[36] Cahn JW, Shechtman D, Gratias D (1986) Indexing of icosahedral quasiperiodic crystals. J Mater Res 1:13-26

[37] Calvayrac Y, Quivy A, Bessière M, Lefebvre S, CornierQuiquandon M, Gratias D (1990) Icosahedral AlCuFe alloys: towards ideal quasicrystals. J Phys France 51:417-431

[38] Asahi N, Maki T, Matsumoto S, Sawai T (1994) Quasicrystallization characteristics of mechanically alloyed $\mathrm{A}_{65} \mathrm{Cu}_{20} \mathrm{Fe}_{15}$ powder. Mater Sci Eng A 181(182):841-844

[39] Barua P, Murty BS, Srinivas V (2001) Mechanical alloying of $\mathrm{Al}-\mathrm{Cu}-\mathrm{Fe}$ elemental powders. Mater Sci Eng A 304-306:863-866

[40] Murty BS, Koteswara Rao RV, Mukhopadhyay NK (2004) Stability of quasicrystalline phase in $\mathrm{Al}-\mathrm{Cu}-\mathrm{Fe}, \mathrm{Al}-\mathrm{Cu}-\mathrm{Co}$ and Al-Pd-Mn systems by high energy ball milling. J NonCryst Solids 334 \& 335:48-51

[41] Mukhopadhyay NK, Ali F, Srivastava VC, Yadav TP, Sakaliyska M, Surreddi KB, Scudino S, Uhlenwinkel V, Eckert J (2011) Strain-induced structural transformation of single-phase $\mathrm{Al}-\mathrm{Cu}-\mathrm{Fe}$ icosahedral quasicrystal during mechanical milling. Philos Mag 91:2482-2490

[42] Ali F, Scudino S, Gorantla SM, Srivastava VC, Shahid HR, Uhlenwinkel V, Stoica M, Vaughan G, Mukhopadhyay NK, Eckert J (2013) Mechanically driven phase transformation in single phase $\mathrm{A} 162.5 \mathrm{Cu} 25 \mathrm{Fe} 12.5$ quasi-crystals: effect of milling intensity. Acta Mater 61:3819-3830

[43] Shadangi Y, Shivam V, Singh MK, Chattopadhyay K, Basu J, Mukhopadhyay NK (2019) Synthesis and characterization of $\mathrm{Sn}$ reinforced $\mathrm{Al}-\mathrm{Cu}-\mathrm{Fe}$ quasicrystalline matrix nanocomposite by mechanical milling. J Alloys Comp 797:1280-1287

[44] Yong X, Chang IT, Jones IP (2005) Formation of a quasicrystalline phase in mechanically alloyed A165Cu25Fe15. J Alloy Compd 387:128-133

[45] Tiwari RS, Yadav TP, Mukhopadhyay NK, Shaz MA, Srivastava ON (2009) Nanocrystallization and structural correlation in quasicrystalline and crystalline phases during mechanical milling. Z Kristallogr 224:26-30

[46] Krendelsberger N, Weitzer F, Schuster JC (2007) On the reactions and liquidus surface in the ternary system Al-Fe-Si. Metall Mater Trans A 38A:1681-1691 
[47] Olsson S, Eriksson F, Birch J, Hultman L (2012) Formation of $\alpha$-approximant and quasicrystalline $\mathrm{Al}-\mathrm{Cu}-\mathrm{Fe}$ thin films. Thin Solid Films 526:74-80

[48] Barua P, Srinivas V, Murty BS (2000) Synthesis of quasicrystalline phase by mechanical alloying of A170Cu20Fe10. Philos Mag 80:1207-1217

[49] Avar B, Gogebakan M (2009) Synthesis of the quasi-crystalline phase in $\mathrm{Al} 63 \mathrm{Cu} 25 \mathrm{Fe} 12$ powders prepared by mechanical alloying. J Optoelectr Adv Mater 11:460-1463

[50] Nicula R, Turqier F, Stir M, Kodash VY, Groza JR, Burkel E (2007) Quasicrystal phase formation in $\mathrm{Al}-\mathrm{Cu}-\mathrm{Fe}$ nanopowders during field activated sintering (FAST). J Alloys Comp 434-435:319-323

[51] Salimon AI, Shevchukov AP, Stepashkin AA, Tcherdyntsev VV, Olifirov LK, Kaloshkin SD (2017) Mechanical alloying as a solid state route for fabrication of $\mathrm{Al}-\mathrm{Cu}-\mathrm{M}(=\mathrm{Fe}, \mathrm{Cr})$ quasicrystalline phases. J Alloys Comp 707:315-320

[52] Ali R, Akhtar MU, Zahoor A, Ali F, Scudino S, Shahid RN, Tariq NH, Srivastava VC, Uhlenwinkel V, Hasa A, Eckert J (2020) Study of thermal and structure characteristic of mechanically milled nanostructured $\mathrm{Al}-\mathrm{Cu}-\mathrm{Fe}$ quasicrystals. Mater Chem Phys 251:123071

[53] Fleury E, Lee JH, Kim SH, Kim WT, Kim JS, Kim DH (2003) Spark plasma sintering of $\mathrm{Al}-\mathrm{Si}-\mathrm{Cu}-\mathrm{Fe}$ quasi-crystalline powder. Metall Mater Trans A 34A:841-849

Publisher's Note Springer Nature remains neutral with regard to jurisdictional claims in published maps and institutional affiliations. 